\title{
anatomy
}

Historical View

www.anatomy.org.tr

Received: Fune 10, 2019; Accepted: Fuly 14, 2019

doi:10.2399/ana.19.062

\section{Mystery of Anatomy: Robert Knox}

\author{
Şenay Gül ${ }^{1}$ iD), Serap Şahinoğlu² (iD \\ ${ }^{1}$ Faculty of Nursing, Hacettepe University, Ankara, Turkey \\ ${ }^{2}$ Department of Medical History and Ethics, School of Medicine, Ankara University Ankara, Turkey
}

\begin{abstract}
Anatomy has been an integral part of medical education for thousands of years. From the past to the present, the corpses on the dissection tables have often been the bodies of people dismissed by the community, such as dead prisoners or the homeless. While dissection studies continued in a similar manner until the early nineteenth century, the works of Robert Knox, an anatomist from Edinburgh, played an important role in the emergence of the Anatomy Act, one of the most striking developments in the field of anatomy. Robert Knox was a scientist not only interested in anatomy but also art. His contributions to anatomy and his work in the field of art failed to attract sufficient and necessary attention due to murders of innocent people committed by William Hare and William Burke. They murdered these people in order to ensure the supply of cadavers to anatomists and physicians and compromised Robert Knox as a knowing participant. This study aims to bring Robert Knox's contributions to anatomy and art to light by considering the period in which he lived, the Industrial Revolution.
\end{abstract}

Keywords: anatomy; anatomy act; art; dissection; Robert Knox

Anatomy 2019;13(2):126-135 @2019 Turkish Society of Anatomy and Clinical Anatomy (TSACA)

\section{Introduction}

Especially after the Renaissance, the human body sparked the curiosity of physicians and artists who went to great lengths to explore it. All these efforts accelerated anatomical studies, which have been essential for the development of medicine since that time. Intellectuals of the period turned away from scholastic philosophy and began to question the conviction of the Church that the human body was sacred. Human dissection played a key role in the development of medicine and anatomy. The Industrial Revolution in Britain, which took place in the eighteenth and nineteenth centuries, deeply influenced modern medicine with increasingly growing interest in anatomy and dissection. However, the difficulty in obtaining cadavers led to the seeking of alternative solutions. Initially, the bodies of executed prisoners were being dissected, but this was not enough. Therefore, physicians and researchers turned to new solutions, such as grave robbing, and the use of corpses for their anatomical studies..$^{[1-3]}$

This study will discuss Robert Knox's professional life, the difficulties that he had in obtaining cadavers, the relationship between anatomy and art, and the impact of the Industrial Revolution on medical developments. Robert Knox worked as a physician and anatomy teacher at the University of Edinburgh, School of Medicine. Despite difficulties in supplying cadavers, he managed to work on dissections and exhibit the corpses that he had dissected in order to immortalise them. Undoubtedly, another important aspect of this study is the Anatomy Act of 1832, which removed the legal obstacles to anatomical study and dissection Robert Knox had difficulty to obtain cadavers, and therefore, resorted to what we would now consider illegal ways. One's life is best understood when the period in which one lived is taken into account. The methods used to obtain cadavers at that time are illegal and unethical today; however, this

This study was presented as an oral presentation at the 2nd International Turkish Medical History Congress of Society for Medical Ethics, Law and History (25-29 October, 2018, Afyonkarabisar, Turkey.). 
study prioritised the historical dimension of the phenomenon in question.

\section{A Brief History of Anatomy and Dissection}

Anatomy is the first branch of science that has been evolving from ancient times and taught to medical science. ${ }^{[1]}$ Our curiosity about the human body dates back to ancient times. The dissection of human bodies is as old as the direct exploration of human anatomy. However, physicians in Ancient Greece avoided dissecting cadavers because they regarded the human body as sacred and honourable. ${ }^{[2]}$ Dissecting cadavers was a regular practice in Alexandria between the fourth century B.C. and fourth century A.D. However, it was not practiced until the sixteenth century due to the prohibitions of the Catholic Church. ${ }^{[3-5]}$

Corpses dug up by grave robbers and those of executed prisoners were the only source of bodies for anatomists, from those who performed the early dissections in Alexandria in 300 B.C. to the anatomists of the seventeenth century in Britain ${ }^{[6]}$ The three most prominent anatomists of the Medical School of Alexandria were Praksagoras, Herophilos and Erasistaratos. ${ }^{[3]}$ Herophilos (335-280 B.C.) was the student of Praksagoras and regarded as the first scientist to dissect the human body. ${ }^{[3,7]}$ Herophilos is considered to be the founder of anatomy, because he dissected human and animal cadavers and contributed significantly to the science of anatomy of that era. ${ }^{[8]}$ Although this environment of freedom enjoyed by Herophilus and Erasistratus did not last long, it was not completely over. ${ }^{[4]}$ For example, Galenus (A.D. 128-200) went to Alexandria for medical education and dissected monkeys and pigs as it was then forbidden to dissect the human body at that time. ${ }^{[3,7]}$ His greatest mistake was that he extrapolated his findings on the anatomy of animals to the human anatomy. ${ }^{[2,7]}$ Galenus refrained from dissecting the human body probably due to the prohibitions of and his close ties with the Church.

The Church's ban on the dissection of human corpses, which was based on its teachings on the sanctity of the human body in the Middle Ages, also caused people to approach dissection with feelings of discomfort and suspicion. Human cadavers were hard to obtain, and therefore, physicians and students had to work on anatomical models and drawings, which were inadequate, however. They needed human cadavers to dissect and study anatomy. ${ }^{[2]}$
Human dissections started to be carried out towards the end of the Middle Ages in Europe ${ }^{[4,5]}$ Back then, numerous Arabic medical texts were translated into Latin, ${ }^{[2,5]}$ such as Kitāb Kāmil al-Şina 'ab al-Tibbiyab (Complete Book of the Medical Art) - also called al-Kitāb alMalikī (Royal Book) by 'Alī ibn al-'Abbās al-Majūs̄̄ (Haly Abbas), al-Kitāb al-Hāwō fì al-Tibb (Comprehensive Book on Medicine) by Abū Bakr Muhammad ibn Zakariyyā al-Rāzī (Rasis or Rhazes) and Kitāb al-Qānūn fì al-Tibb (Canon of Medicine) by Ibn Sīnā (Avicenna). Those works played a key role in the development of medicine from the end of the eleventh to the beginning of the fifteenth century. The detailed anatomical information in the Great Arabic medical compilations such as Ibn Sīnā's Kitāb al-Qūnūn fì al-Tibb (Canon of Medicine) and Ibn Rushd (Averroes)'s Kitāb al-Kulliyāt (The Book of General Principles) provided new insights and aroused interest in the subject. ${ }^{[2]}$

At the end of the twelfth century, the educators of the Salerno School of Medicine performed animal dissections in their lectures, yet once a year or less. Frederick II decreed that medical schools be allowed to dissect one human body once every five years. In 1299, Pope Boniface VIII promulgated a bull referred to as Detestande Feritatis (of Detestable Cruelty) prohibiting the dissection of the human body for any but a limited number of forensic reasons. ${ }^{[2,3,5]}$

Some interventions used to be carried out on cadavers for various reasons. For example, dead bodies that were to be brought back to their home countries to be buried used to be embalmed in the middle of the fourteenth century. Cadavers were also dissected to remove internal organs, determine the cause of death, investigate suspicious deaths or epidemics, check for specific signs on the bodies of deceased saints or investigate whether someone died due to witchcraft or natural causes. ${ }^{[2-5]}$

Mondino de Luzzi (1275-1321) was the first after Herophilos to dissect cadavers to study anatomy. ${ }^{[2-5,9]}$ Henri de Mondeville (1260-1316), who was the surgeon of Philip IV and Louis X of France, states in his book entitled La Chirurgie (1312) that one must obtain special permission from the Roman Church to remove the internal organs of cadavers. ${ }^{[5]}$

Difficulties in dissection practices continued until Andreas Vesalius (1514-1562). Vesalius published his masterpiece De Humani Corporis Fabrica Libri Septem (On the Fabric of the Human Body in Seven Books) in 1543 based on his dissection practices. ${ }^{[2,3,5,8]}$ His work on human dissection helped him find errors in anatomy books. He highlighted the significance of observation by 
stating, "If anyone wishes to observe the works of Nature, he should put his trust not in books on anatomy but in his own eyes...". ${ }^{[3,10,1]}$ Vesalius's work presented his successors with the errors of the Galenus anatomy. He played a key role in the development of the science of anatomy by pointing at the dissection tables. ${ }^{[5,8,9]}$

Another important point in the development process of anatomy is the spaces where dissection studies are performed. After the sixteenth century, physicians built anatomical theatres not only to perform human dissection for their own research but also to stage public displays. One of those anatomical theatres was a mobile theatre at the University of Montpellier in France. The first stationary theatre was built in 1584 in Padova ${ }^{[5]}$ In the 1600s, human dissections turned into a form of spectacle, which allowed professors to show their skills. It was, however, more of a spectacle than empirical investigation..$^{[2]}$

Nevertheless, spectators developed distaste for those public displays because they thought that dissection rendered both the individual and social personality of those who were dissected unrecognisable and stripped them of their right to burial. This negative attitude towards dissection began to change with an increased interest in science in the eighteenth century. In Europe, anatomy progressed, and the decline in capital punishment especially in some countries led to a shortage of cadavers for medical schools. ${ }^{[12]}$

The Murder Act on the use of bodies of executed prisoners for anatomical studies and research was passed in 1751 in Britain. It had two objectives: (1) to prevent horrific murders and denial of burial to offenders and (2) to create a legal basis to supply corpses for anatomical research. ${ }^{[11]}$ The government also increased the number of criminals to be executed in order to supply human bodies for anatomical research. ${ }^{[13]}$ Despite all these efforts, the number of cadavers supplied to medical schools was insufficient due to the rapid increase in the number of medical and anatomical studies. Some European countries enacted laws that allowed medical students to dissect the bodies of prisoners, mental patients who committed suicide and paupers who died in hospitals. ${ }^{[12]}$ Back then, paupers seeking medical care had to sign a secret contract that stipulated that they pay the physician the "thing" that they owed to the hospital. The "thing" referred to the "body" to be used for medical and scientific research. ${ }^{[1]}$

However, the situation was a bit different in Britain, where laws on the use of unclaimed bodies were not accepted until the beginning of the nineteenth century. ${ }^{[2]}$
Something had to be done to stop the murders committed by Bishop and Williams in London and by Burke and Hare in Edinburgh to supply cadavers to medical schools. ${ }^{[13,14]}$

In 1828 in Britain, a government committee, set up under the leadership of the neuroanatomist Herbert Mayor, reported the problems of anatomists, and the Anatomy Act was adopted in 1832, which decreed that the bodies of unclaimed paupers who had died in elderly care homes and hospitals be given to licensed anatomists for dissection. The "unclaimed" were those whose bodies had not been claimed within forty-eight hours after death. The Act changed the paradigms of cadaver acquisition for anatomical research. While the Law did not allow the use of bodies of executed prisoners for dissection in accordance with human rights and dignity, it made the donation of such cadavers possible. ${ }^{[1,15,16]}$ The Act established the legal basis for the supply of cadavers for anatomical research. The poor began to sell the bodies of their deceased relatives to medical schools. In addition, cadaveric donation ushered a new era in the field of medicine ${ }^{[6]}$ The Law remained in force until the Human Tissue Act was adopted in 2004. ${ }^{[16]}$

The legalisation of the use of unclaimed bodies and those of executed prisoners for dissection paved the way for the development of anatomical research in many countries. ${ }^{[17-19]}$ The Anatomy Act was the first regulation passed by the British government on this subject with not only social but also political and economic ramifications. The Act also made it possible for medical education as well as the field of medicine to proceed in a coherent, reproducible and scientific way. The next section will address Robert Knox, both an anatomy teacher and artist, who played a key role in the passing of the Anatomy Act.

\section{The Life and Works of Robert Knox}

Robert Knox was born in 1791 in Edinburgh during the Industrial Revolution (Figure 1a). ${ }^{[20]}$ His works on dissection made significant contributions to anatomy and the training of numerous medical students. Knox began his medical education at the Edinburgh School of Medicine in 1810 and failed the anatomy class taught by the Professor of Anatomy, Alexander Monro II. To pass anatomy, Knox attended the anatomy class of Dr. John Barclay, who had an international reputation in the field. Knox graduated from the Edinburgh Medical School in 1814 and worked at St. Bartholomew's Hospital in London for one year. He served as an army surgeon in 

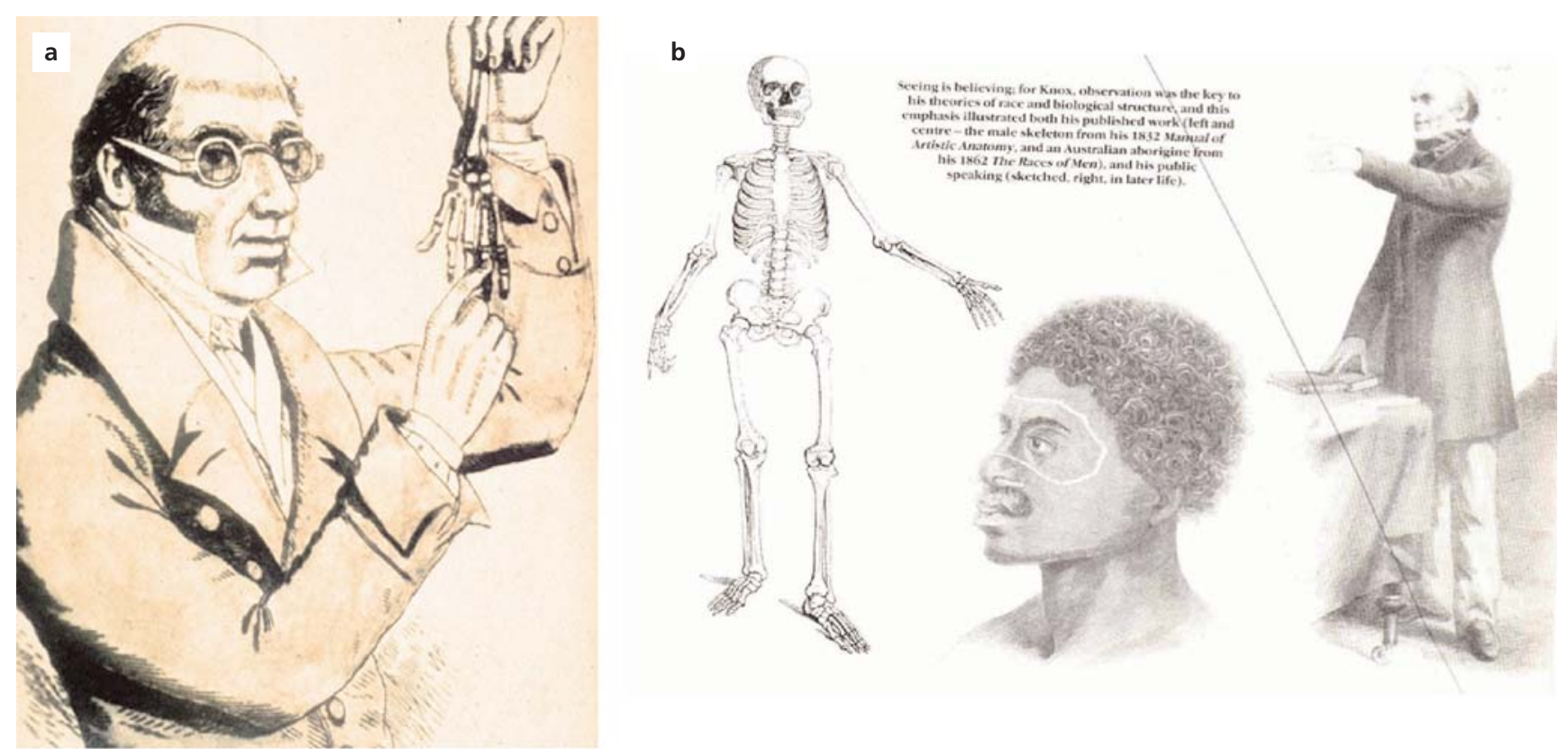

Figure 1. Robert Knox $(\mathbf{a})^{[20]}$, some of his illustrations $(\mathbf{b})^{[20]}$. [Color figure can be viewed in the online issue, which is available at www.anatomy.org.tr]

Brussels, and his first task was to deal with the wounded of the Battle of Waterloo. ${ }^{[1-24]}$

The Industrial Revolution, which took place in the United Kingdom from around 1760 to 1830 and marked the beginning of modern age, signifies a shift from an agrarian to an industrial economy especially with the invention of the steam engine in 1775 by James Watt. ${ }^{[2,26]}$

The spirit of scientific research and innovation of the Industrial Revolution prompted scientists to unlock the secrets of the human body, which is the most perfect and complex of all machines. The human body was subject to a level of scrutiny that it had never before experienced, and its secrets began to be disclosed. ${ }^{[27]}$ Numerous contagious diseases were transferred across the oceans due to colonialism and slavery, which gained momentum with the Industrial Revolution. ${ }^{[1]}$ During that period, Knox visited South Africa and conducted an extensive study on the history and anthropology of the Cape of Good Hope. He devoted a large part of his life to study and develop ethnological theories on the anatomical features of African people (Figure 1b). ${ }^{[20]}$ After serving as an army officer until 1820, he turned to a different career path and became an educator. In 1821, he began to live in Paris, which was then the center of contemporary anatomical debates, and met Etienne Geoffroy SaintHilaire and Georges Cuvier (Georges-LéopoldChrétien-Frédéric-Dagobert- Baron Cuvier), two giants of comparative anatomy. Knox became familiar not only with the theories of Cuvier and Saint-Hilaire on comparative anatomy but also with the new ideas of racism and colonialism. ${ }^{[23,24]}$

After Knox returned to Edinburgh in 1822, he started to work in the Chair of Anatomy of the School of Medicine at the University of Edinburgh upon the proposal of Dr. John Barclay. He published his studies on the treatment of necrosis, bone regeneration, pericarditis and tapeworm in the Edinburgh Medical Journal between 1821 and $1823 .^{[21-24]}$

Knox proposed a plan for a museum of anatomy to exhibit the comparative anatomical samples, which had been collected by Dr. John Barclay for more than twenty years. After the adoption of the plan in 1825 , Knox was appointed as the founding executor of the Museum of Comparative Anatomy in 1826 and remained in that post until $1831 .^{[21-24]}$ The same year, following the death of John Barclay, Knox started to teach anatomy and surgery to about 300 students in the Department of Anatomy of the Edinburgh School of Medicine. He also performed a large number of dissections during that period. During the 1827-28 academic year, Knox taught 504 students, including nobles, jurists, artists and writers, in Britain's largest anatomy class. ${ }^{[0]}$

Knox was Edinburgh's most successful and independent anatomy teacher. ${ }^{[21-22]}$ With his scientific articles published in Lancet and Medical Gazette magazines, he con- 
tributed significantly to medicine, anatomy, comparative anatomy and zoology. His work entitled "Contributions to Anatomy and Physiology" attracted the attention of many scientists. His lectures on anatomy, physiology and pathology published in the Medical Times were very useful to many medical students. He also published his lecture notes on "Human Anatomy for Artists" inspired by his own experience and Leonardo Da Vinci. Emphasising that zoology should be used for anatomical studies; Knox also gave lectures on ethnology. ${ }^{[2]}$

In the following years, Knox got involved in a scandal that ruined his life and had to leave Edinburgh. ${ }^{[9]}$ This will be discussed in more detail in the next section. His license to teach anatomy was withdrawn, and he stayed in London until the end of the 1840s, writing more on anatomy. He also started a new career as a wandering lecturer, in which he taught lectures on ethnology and race and published works on anatomy that were useful not only for physicians, but also for artists and zoologists. $^{[23]}$

He tried to give a new direction to race studies and devoted many years of his life to recording most information on physical and the bone structures and nervous systems of different races and embarked on long journeys for doing so. He was also interested in human history. During his years in Africa, he objectively examined human relations as well as the wild, social and intellectual life using scientific methods. To him, race was everything, and literature, art and civilisation developed around it. ${ }^{[20]}$

Knox witnessed the kinship of races and the solidarity and ties between peoples. He argued that patriotism, social spirit and the preservation of national life depended on the homogeneity of the race. According to him, racism played a critical role in the rapid rise of Napoleon Bonaparte to power. ${ }^{[2]}$ The Races of Men (1850) is regarded as the highlight of Knox's career. ${ }^{[13,20,21,28]}$ Biddiss argues that Knox and Hitler's views of race were different from each other. Knox examined race in a scientific and systematic way to contribute to the knowledge of comparative anatomy. Interestingly, Knox, the founder of scientific racism, was alleged to be an anti-colonialist since he began working in South Africa. ${ }^{[20,28]}$

Robert Knox's scientific works (1825-1850) contributed to the development of racism in Europe. In general, it does not come as a surprise when someone who is interested in medicine is also interested in race. What is surprising is that race studies did not attract the attention of those who were involved in medicine. Knox's views of racism were rarely addressed or mostly misunderstood by social scientists. Before him, no one established a nexus between race and anatomy. His works made sure that the significance of the nexus between these two notions was recognised by medical students, across the country and abroad. ${ }^{[2]}$

Knox's career ended as an under-paid anatomist at the Brompton Cancer Hospital in London British authorities barred Knox from employment at Edinburgh University, and he was unable to perform his profession in London until the Medical Act was passed in 1858 . He was appointed Honorary Member of the London Society of Ethnology in 1860 and First Member of the first anthropological Society of Paris in 1861. Although he sought an academic position in Britain during that period, it was to no avail. . $13,20,21,24,28]^{2}$

Robert Knox died at his home on December 9, 1862 and was cremated and buried at a funeral attended by his former students on December 29, 1862. Knox's grave was simply forgotten. In 1966, Sir John Bruce and Professor Eric Mekie, two of Knox's successors at the Surgical Clinic of the University of Edinburgh, had his grave cleaned up and had a fine memorial placed upon the site..$^{[13,20]}$

\section{The Burke and Hare Murders}

Robert Knox is known as anatomist who bought the corpses of the victims of murderers William Burke and William Hare from Edinburg. ${ }^{[23]}$ Before the Anatomy Act came into force in 1832, anatomists were only allowed to dissect the cadavers of executed prisoners. In the 1700s, there were few students of anatomy and many criminals sentenced to death. Therefore, medical students and teachers did not lack for cadavers. Along with the softening of laws and development of medical education, the number of cadavers supplied to medical schools became more and more insufficient. Therefore, digging up corpses was a practical solution to the problem..$^{[2,23,28,29]}$

However, Burke and Hare's method of obtaining cadavers was much more dramatic. They knew of grave robbers and would have robbed graves themselves; however, they found it too hard and dangerous. One day, an old man who had been renting a room from Hare died. The deceased man had no relatives, and Burke and Hare thought that they could sell his corpse to anatomists for a high price. They had only heard of Alexander Monro III (1773-1859). Monro III was not only a physician but also a renowned anatomy teacher who had 40,000 students throughout his life. Hare and Burke went to 
Surgeon's square to sell the cadaver to Monro. There, they ran into Knox's students who told them that Dr. Knox would pay more than Dr. Monro would. Therefore, the two men handed over the corpse to the students. If Burke and Hare had not run into Knox's students that evening, it would have been Alexander Monro III that would have been charged with these crimes, and Knox might not have written books on anatomy, anthropology and ethnology. Satisfied with the fortune they had made, Hare and Burke thought about the prospects of the venture and began to kill homeless people. They sold sixteen human cadavers to Knox, who had no idea where they had come from. ${ }^{[2,9,24]}$

In November 1828, the body of Ms. Docherty was found in Dr. Knox's cellar at Surgeons' square in Edinburgh. Since it was a dissection room, it was not surprising to find a human body there. However, the authorities were suspicious that the cadaver had been brought there by illegal means. Knox had great difficulty obtaining a sufficient number of cadavers for his dissection practices, and therefore he, like his colleagues, did not question where all the bodies were coming from. The forensic investigation into Ms. Docherty's death revealed that the cause of death was strangulation. ${ }^{[1,22,23,28]}$

This shocking truth brought all of Britain - and of course Knox - into discredit. In hindsight, Knox was not actually responsible for those murders. He was never summoned to court and was never found guilty of any contravention. However, many physicians and the public associated him with those murders. ${ }^{[2]}$ Burke was publicly executed and then dissected by Dr. Monro, and books, wallets and bags were made from his skin and sold on the streets. Hare was released. ${ }^{[0,31]}$

There is no doubt that all those incidents had a social, legal and ethical dimension. Were the cadavers of paupers and prisoners dissected according to their own wishes, or were they murdered specifically to be dissected? The answers to these and similar questions are probably not positive. This study focused on the historical dimension of the subject matter and excluded the above questions and discussions.

\section{Anatomy and Art}

Despite bringing cadavers, dead bodies, and thus death into mind, anatomy is a science that examines the structure and vital functions of normal, healthy and living bodies as well as body parts. Art is a concept and activity that always exists in parallel with life. A human being is at the intersection of art and anatomy. The zeal for the detailed and accurate depiction of human anatomy resulted in a more realistic illustration of the human body. ${ }^{[32]}$

Anatomy and art actually go together like a horse and carriage. The better we understand the anatomical details of the human body, the more easily and successfully we can assign a meaning to them. Knowing about the proportions of human face, the wrinkles that come with age and gestures and their anatomical details plays a key role in reflecting feelings such as happiness, fear and anxiety expressed mostly by facial gestures. ${ }^{[3]}$

Renaissance art took on a unique character with the branches of science, especially anatomy and mathematics. Both artists and physicians sought accurate anatomical information. Artists placed a new emphasis on the accurate representation of animals and plants, the scientific use of the perspective and the idea that the human body is beautiful and worthy of contemplation, and therefore, they performed anatomy and dissection studies tolearn about the human body in greater detail. ${ }^{[4]}$

Leonardo da Vinci (1452-1519) comes to mind when we think about the zeal to illustrate the human body in the most accurate way. His works depicting the human body are based on his anatomical studies. He was a painter, inventor, anatomist, theorist, philosopher, musician and teacher and made significant contributions to art, literature, science and technology. Therefore, he was one of the greatest and most versatile geniuses not only of the Renaissance but also of all time. ${ }^{[5]} \mathrm{He}$ ingeniously combined his objective observations of nature with his great love for the reproduction of invisible reality through fine arts and painting. His works have inspired numerous artists for centuries. ${ }^{[33]}$

The objective of Leonardo da Vinci was to unravel the internal dynamics of all the fields of his interest and to establish a connection among them. His method was to experiment continuously. Da Vinci model was based on the superior composition and interaction between art and science. Studies on the superficial anatomy of the human body led him inevitably to general anatomy, comparative anatomy and physiology. He believed that through dissection and experimentation he could unlock the mystery behind motor movements and even mechanisms that govern life itself. He, therefore, designed models to study the mechanisms of muscles and heart valves. To him, a painter should know and understand the inner structures of the human body. It is stated that he also dissected human bodies to make his drawings. ${ }^{[32]}$

Scientists had to use drawings when they could not obtain real cadavers for their anatomical studies. Jacopo 
Berengario da Carpi's book entitled Anatomia Carpi published in 1535 was the first illustrated anatomy book. It contains anatomical illustrations of people in front of a landscape background stripping their skin on the abdomen or chest area with their own hands to show the reader what is inside. It is the first educational tool and work on artistic anatomy. After Berengario, a permanent cooperation was established between artists and anatomists. The former brought an aesthetic dimension to anatomy. ${ }^{[5]}$

The Renaissance lifted the taboos on the human body, turning it into something that could be explored. During that era, such artists as Leonardo da Vinci, Michelangelo Buonarroti, Raffaello Sanzio da Urbino, and Albrecht Dürer expected anatomists to guide them, and they even dissected cadavers themselves to satisfy their curiosity. ${ }^{[9]}$ Until the beginning of the nineteenth century, painters mostly studied the human body, visited anatomical theatres and read the physicians' books and met them in person. ${ }^{[1]}$

In conclusion, anatomy is not only a part of medicine but also closely related to art. The illustration of the human body had become important after the sixteenth century. The spirit of the age prompted anatomists to portray the human body and artists to study anatomy. Anatomists not only dissected cadavers but also used their own drawings to teach anatomy. Even today, artists have to learn anatomy. In addition to his studies on anatomy, Robert Knox illustrated the human body and used his drawings in his lectures on anatomy.

\section{Robert Knox's Anatomical and Artistic Works}

Artists are influenced by the art movements of the period in which they live. At the end of the eighteenth and the beginning of the nineteenth century, artists adapted to the spirit of the Enlightenment which prioritised reason to comprehend the world and began to imagine more rational and vivid works inspired by antiquity. This new school of thought is referred to as Neoclassicism, also known as 'noble simplicity andcalm grandeur'. The ancient Greek and Roman civilisations became the inspirational sources of artists, and Rome became the centre of Neoclassicism and a meeting point for them. The Enlightenment, the Industrial Revolution, and the collapse of the absolutist feudal system upset the perceptions of God, humanity and the world. Christianity began to lose its grip on society. Of course, this revolution in value judgments resonated with art as well. Religious motifs, which were dominant in the art of painting until the Baroque period, were almost lost.
Mythology was replaced by history, and the place of art in society was redefined. Art became a public phenomenon especially after the French Revolution. Artists took on a new role with the opening of the traditional art market to the public. They began to choose their own subject matters and approach them from their own perspective. ${ }^{[3]}$ Before the Industrial Revolution, art and artists were under the strict rules, and therefore, not original and free. The Industrial Revolution destroyed the rigid rules and taboos. ${ }^{[35]}$

Having also been influenced by the art movements of the era, Robert Knox and other anatomists used more independent and realistic anatomical illustrations, which became a necessity for lectures on anatomy. Knox's views of art are compatible with Neoclassicism. In his book entitled A Manual of Artistic Anatomy: For the Use of Sculptors, Painters and Amateurs, Robert Knox stressed that even emotions should be illustrated in a specific way. ${ }^{[23,36]}$

For Knox, the object of art is to represent 'nature in her finest forms, in her highest manifestations of matter', and to capture perfection and beauty. ${ }^{[22,28]}$ Knox suggested to his students that they study Ancient Greek sculpture and never draw a naked woman without a model of Venus at hand. Knox thought that art and science were in harmony for their broadest purposes, and therefore, encouraged young artists to study anatomy as part of their education. But he also warned: "Artists must know the buman body, but only to the extent that they have an understanding of superficial anatomy and the deeper structures that shape it. Too great a focus on anatomy could divert artists from their bigher aims". ${ }^{[2,23,28]}$ The young artists of the time attended lectures on anatomy at the Royal Academy of Fine Arts and followed courses on anatomy in medical schools to get first-hand knowledge of the human body through dissection. ${ }^{[2]}$

Knox strove to portray reality exactly as it was until the first photograph was taken in 1826 by Joseph Niepce. His drawings have left their mark on this century. Knox also drew some of the cadavers brought to him for dissection. The most remarkable one was that of Mary Paterson. Knox met Mary Paterson when her body was brought into his dissection room. Knox was especially interested in aesthetic anthropometry and its relationship with the fine arts. That is why he said, upon seeing Mary Paterson's body in the anatomy hall, which she had the most perfect body proportions he had ever seen. ${ }^{[2,28]}$

He drew Mary Paterson's perfect body so that future students and generations could also see it. Mary 


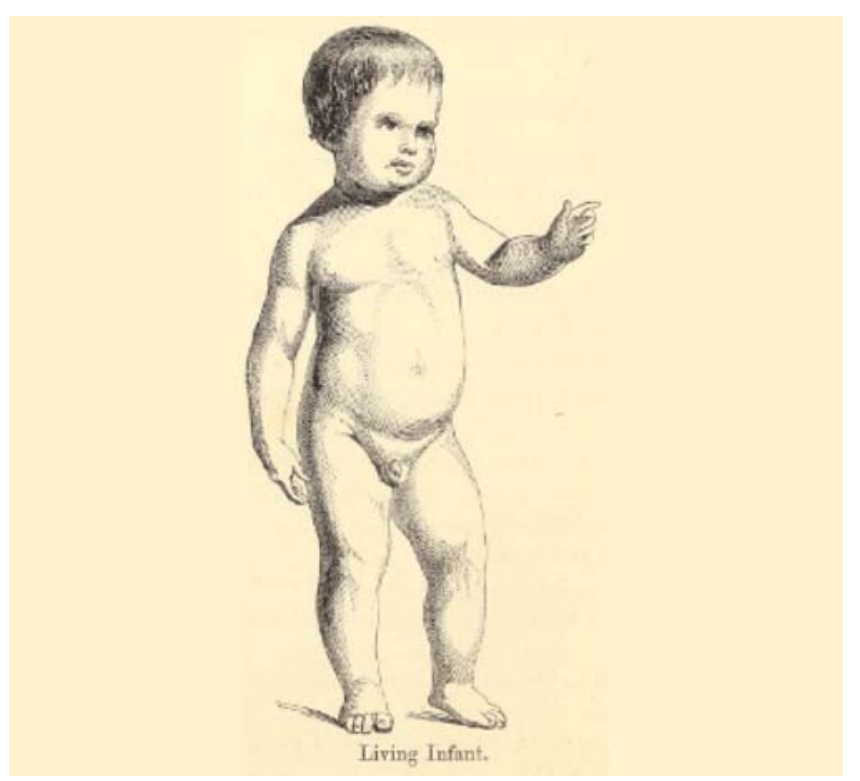

Figure 2. Living infant's body. ${ }^{[36]}$

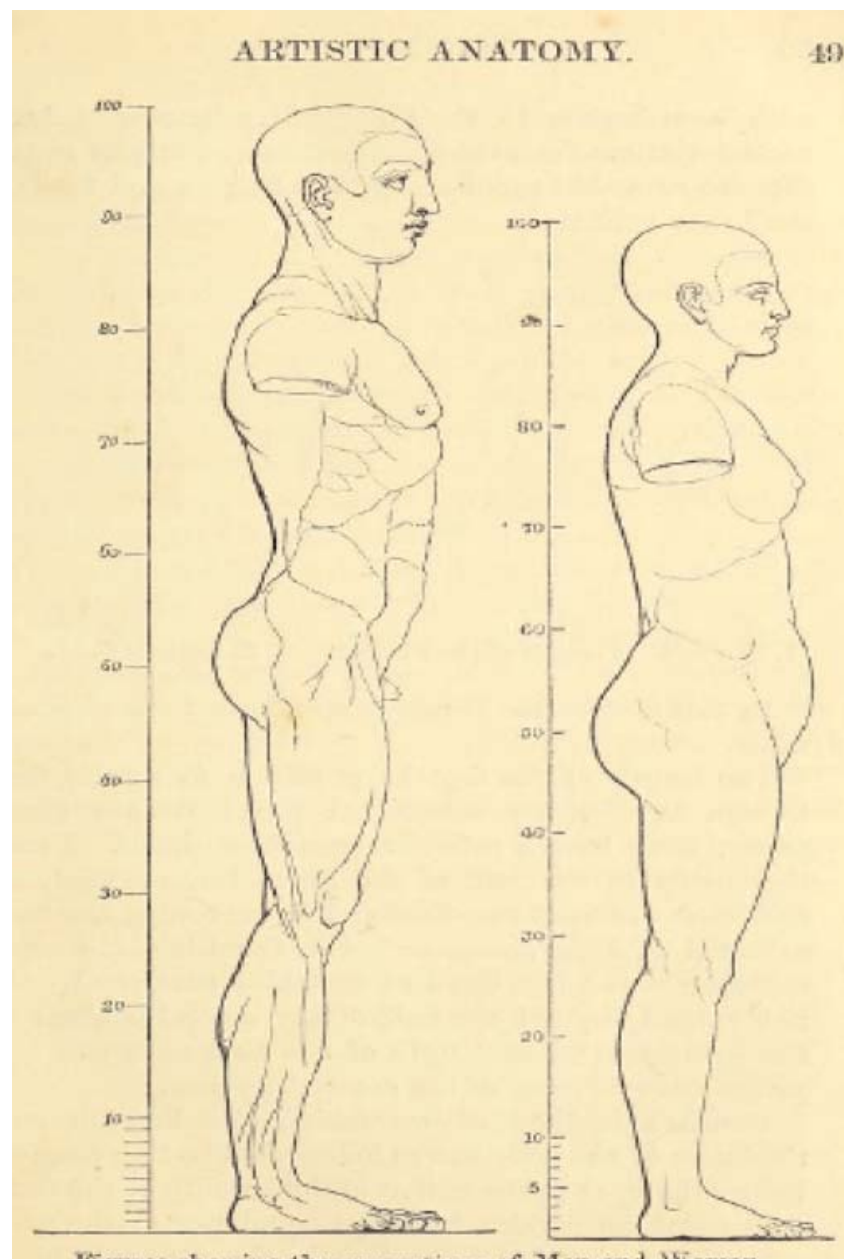

Figures showing tle proportions of Man and Woman.

Figure 3. Male and female body proportions. ${ }^{[36]}$
Paterson's body had become an aesthetic object for artists and intellectuals and was on display until it began to decay. It was then embalmed in a tank full of alcohol and examined in depth after being exhibited for three more months. ${ }^{[22,28]}$

Knox often made references to Leonardo da Vinci to support his own ideas and argued that da Vinci never mistook the dead for the living. He always drew the dead as the dead and the living as the living. ${ }^{[28]}$ To Knox, old people and infants lacked ideal human forms because the former have wrinkled skin while the latter are underdeveloped (Figure 2). ${ }^{[3]}$ Therefore, according to him, women between the ages of seventeen and twenty-seven possessed ideal bodies. To him, beauty was based on proportions and the outer part of the body, which were at their best during the first period of adulthood (Figure 3) ${ }^{[36]}$, and the interior of the human body was unaesthetic. Knox stated that the exterior of the human body belonged to art and the internal (organs, etc.) belonged to science. $^{[22,23,28]}$

Knox compiled his views of artistic issues in his books entitled A Manual of Artistic Anatomy: For the Use of Sculptors, Painters and Amateurs and Great Artists and Great Anatomists: A Biographical and Philosophical Study (Figure 4a and $\mathbf{b}){ }^{[3,3,3]]}$ In the introduction of the latter he told his readers: 'The true relation of anatomy to science, philosophy, and art, has not yet received from thinking men the attention it merits'. In order to overcome this deficiency, Knox wrote this book by taking into account the opinions of Leonardo Da Vinci, Michelangelo, Raphael, Cuvier and Saint Hilaire. However, after the Burke and Hare incident, Knox lost his position in the official history of anatomy, and he was erased from the history of art in Britain in the nineteenth century. ${ }^{[2,28]}$

\section{Discussion}

Science witnessed significant progress especially in the nineteenth century, and scientific advances gained a new impetus with advances in anatomy. We cannot deny the fact that the Anatomy Act played a key role in this process.

Before the Hare and Burke murders, Knox was one of Britain's most famous, unique and influential anatomists. However, Knox's involvement with Burke and Hare left him with financial difficulties and a bad reputation for the rest of his life. ${ }^{[20,24,28]}$ The Anatomy Act was passed after the Hare and Burke murders.

However, Knox's life, career and fame also changed. ${ }^{[3]}$ He was never formally accused, far less convicted of any 

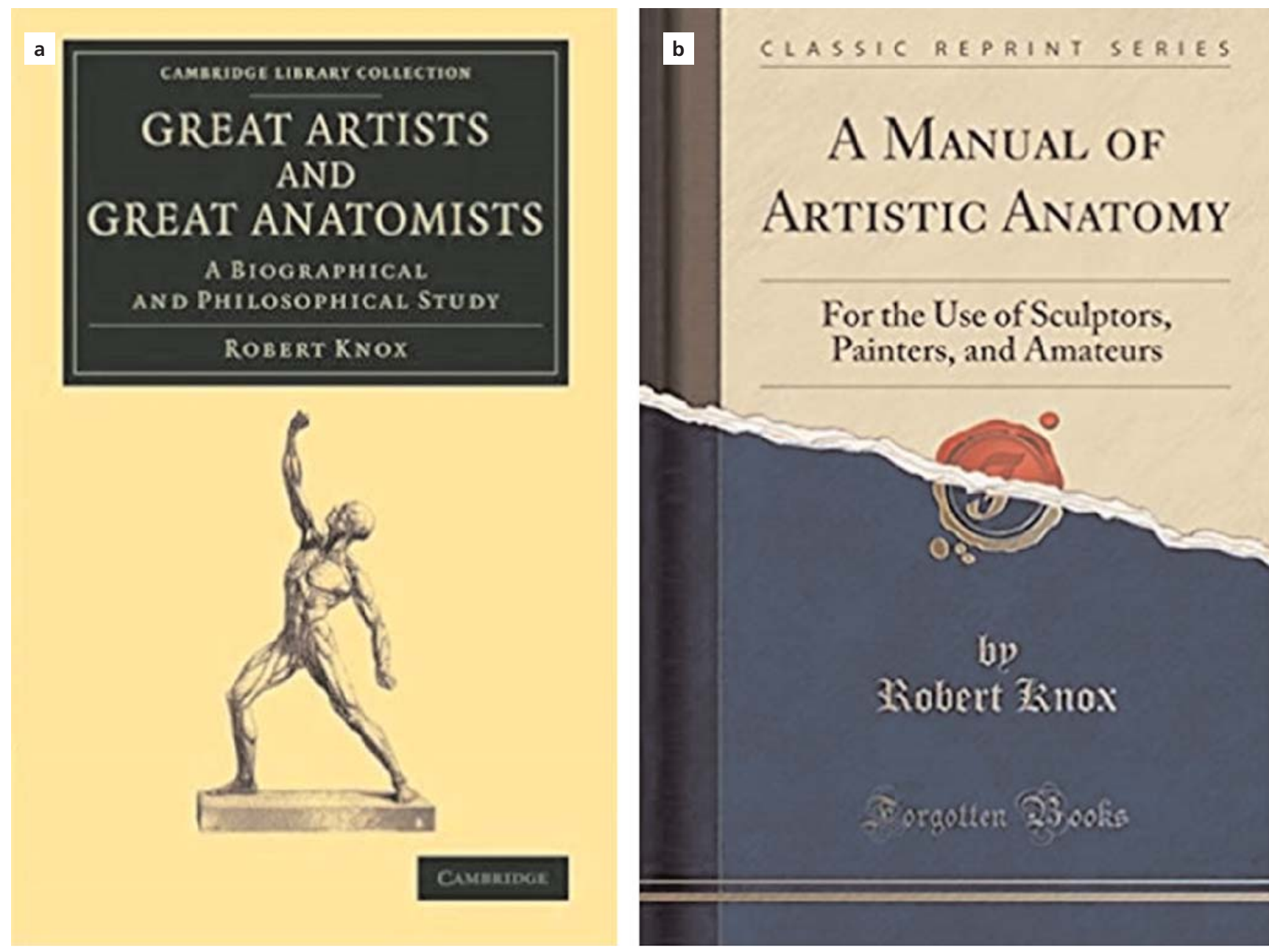

Figure 4. The books of Robert $\operatorname{Knox}(\mathbf{a}, \mathbf{b}){ }^{[36,37]}$ [Color figure can be viewed in the online issue, which is available at www.anatomy.org.tr]

crime. ${ }^{[39]}$ He diverted his attention to other fields of science such as ethnology and anthropology. ${ }^{[38]}$

Knox was a very intelligent and ambitious scientist. As reported by Lonsdale, who was one of Knox's students, Knox and Monro were always compared to each other because both were successful educators. The fact that their students and contemporaries described Knox as a better educator than Monro did nothing but intensify the competition between the two. ${ }^{[2]}$

Who can or should be the subject of history, of medical history? Robert Knox was left to be forgotten because he was found guilty based on the moral and legal standards of the period in which he lived. Today, finding out what really happened back then is impossible. It is, however, undeniable that Knox's studies on race, dissection, anatomy, ethnology and anthropology, and his views of arts and aesthetics made significant contributions to science, medicine, philosophy and art. He also trained elite physicians, which is his other contribution to medicine.

Knox's life has been the subject of numerous books, articles, plays, films and television series, all of which have allowed us to get to know him as an anatomist who had been excluded from the history of medicine. However, the current enthusiasm for Knox has more to do with the mystery and horror of the Hare and Burke murders arousing people's curiosity rather than Knox's contributions as an artist and scientist.

\section{Conclusion}

Robert Knox was found guilty based on the moral and legal standards of the period in which he lived. However, undoubtedly, he was both an accomplished anatomist and an avant-garde figure who made significant artistic contributions to anatomy. 


\section{References}

1. Faure O. [Hekimin bakışı]. In: Corbin A, Courtine JJ, Vigarello G, editors. Histoire du corps 2. İstanbul: Yapı Kredi Yayınları; 2011. p. $15-40$.

2. Porter R. The Cambridge illustrated history of medicine. 3th ed. Cambridge (UK): Cambridge University Press; 2006. p. 154-89.

3. Lyons AS, Petrucelli RJ, Bosch J, Barnert AH. Medicine: an illustrated history. New York (NY): HN Abrams; 1978.

4. Magner LN. A history of medicine. 2nd ed. New York (NY): Taylor and Francis; 1992. p. 203-6.

5. Mandressi R. [Teşrih ve anatomi]. Turkish translation from: Corbin A, Courtine JJ, Vigarello G, editors. Histoire du corps 3. İstanbul: Yapı Kredi Yayınları; 2008.

6. Hildebrandt S. Capital punishment and anatomy: history and ethics of an ongoing association. Clin Anat 2008;21:5-14.

7. Aydın E. Dünya ve Türk tıp tarihi. Ankara: Güneş Tıp Kitabevleri; 2016.

8. Bayat AH. Tip tarihi. İzmir: Sade Matbaa; 2003. p. 27-9, 95-7, 115-7, 129, 137-9.

9. Uzluk FN. Robert Knox'un uğradığı felaket. In: Uzluk FN, editor. Genel tup tarihi I. Ankara: İstanbul Matbaasi; 1958. p. 221-2.

10. Arda B, Kahya E, Başağaç Gül T. Bilim etiği ve bilim tarihi. 2. baskı. Ankara: Ankara Üniversitesi Basımevi; 2009. p. 21.

11. Kahya E, Öner M. Biyoloji tarihi. Ankara: İmge Kitabevi; 2007. p.111-3, 129-36, 151-4.

12. Mitchell PD, Boston C, Chamberlain AT, Chaplin S, Chauhan V, Evans J, Witkin A. The study of anatomy in England from 1700 to the early 20th century. J Anat 2011;219:91-9.

13. Richards E. The "moral anatomy" of Robert Knox: the interplay between biological and social thought in Victorian scientific naturalism. J Hist Biol 1989;22:373-436.

14. Rosner L. The anatomy murders. Philadelphia (PA): University of Pennsylvania Press; 2009.

15. Richardson R. Death, dissection and the destitute. New York (NY): University of Chicago Press; 2000.

16. The anatomy act. [Internet] [Retrieved: June 1-, 2019]. Available from: [http://www.kingscollections.org/exhibitions/specialcollections/ charles-dickens-2/italian-boy/anatomy-act].

17. Gopichand PV. Editorial. Journal of the Anatomical Society of India. 2002;51:143-4.

18. The Anatomy Act. Canadian Legal Information Institute. [Internet] [Retrieved: June 1, 2019]. Available from: [http://www.canlii.org/mb/ laws/sta/a-80/20060515/whole.html].

19. Walia MS. Unclaimed bodies. 2003. The Tribune online edition 07/ 10/2003. [Internet] [Retrieved: June 1, 2019]. Available from: [http:// www.tribuneindia.com/2003/20030710/ mailbag.htm].

20. Collinson S. Robert Knox's anatomy of race. History Today 1990; 40:44-49.
21. Biddiss MD. The politics of anatomy: Dr. Robert Knox and Victorian racism. Proc R Soc Med 1976;69:245-50.

22. Lonsdale H. A Sketch of the life and writings of Robert Knox, the anatomist. London: Macmillan and Co; 1970.

23. Neher A. Robert Knox and the anatomy of beauty. Med Humanit 2011;37:46-50.

24. Currie AS. Robert Knox, anatomist, scientist, and martyr. Proc R Soc Med 1932;26:39-46.

25. Rostow WW. Sanayi Devrimi nasıl başladı? İstanbul Üniversitesi İktisat Fakültesi Mecmuası 1971;30:1-4.

26. Günay D. Sanayi ve sanayi tarihi. Mimar ve Mühendis Dergisi 2002; 31:8-14.

27. Black J. Kısa İngiltere tarihi. 2. baskı. İstanbul: Say Yayınları; 2018. p.117-51.

28. Bates AW. The anatomy of Robert Knox: murder, mad science and medical regulation in nineteenth-century edinburgh. Brighton: Sussex Academic Press; 2010.

29. Chamberlain AT. Morbid osteology: evidence for autopsies, dissection and surgical training from the Newcastle infirmary burial ground (1753-1845). In: Mitchell P, editor. Anatomical dissection in enlightenment England and beyond: autopsy, pathology and display. Farnham: Routledge; 2012. p. 11.

30. Huisman F, Warner JH. Locating medical history: the stories and their meanings. Baltimore: The Johns Hopkins University Press; 2004. p. 380-5.

31. Mcleod M. Edinburgh's dark history: Burke and Hare. [Internet] [Retrieved: June 1, 2019]. Available from: [https://blog.nms.ac.uk/ 2015/11/02/Edinburghs-dark-history-burke-and-hare/]

32. Pelin C. Sanatta anatomi. In: Bilim, bilim politikası ve üniversiteler. Ankara: Bağlam Yayıncılık; 1997. p. 127-30.

33. Krausse AC. Leonardo da Vinci. Rönesanstan günümüze resim sanatının öyküsü. İstanbul: Literatür Yayıncılık; 2005. p. 14-5.

34. Krausse A. Neoklasisizm. Rönesanstan günümüze resim sanatının öyküsü. İstanbul: Literatür Yayıncılık; 2005. p.51-52.

35. Bulut Ş. 19. yüzyll sanayi devriminin toplum ve sanat üzerine etkileri. Turkish Journal of Arts and Social Sciences 2015;1:1-13.

36. Knox, R. A manual of artistic anatomy: for the use of sculptors, painters, and amateurs. Miami (FL): Hardpress; 2017.

37. Knox R. Great Artists and Great Anatomists: A Biographical and Philosophical Study. UK: Forgotten Books; 2017.

38. Rosner L. The anatomy murders: being the true and spectacular history of edinburghh's notorious Burke and Hare and of the man of science who abetted them in the commission of their most heinous crimes. Philadelphia (PA): University of Pennsylvania Press; 2010.

39. MacLaren I. Robert Knox MD, FRCSEd, FRSEd 1791-1862: the first conservator of the college museum. J R Coll Surg Edinb 2000; 45:392-7.

\footnotetext{
Correspondence to: Şenay Gül, PhD

Faculty of Nursing, Hacettepe University,

06100, Sihhiye, Ankara, Turkey

Phone: +90 3123051580

e-mail: senaygundogmus@gmail.com
}

Conflict of interest statement: No conflicts declared.

This is an open access article distributed under the terms of the Creative Commons Attribution-NonCommercial-NoDerivs 3.0 Unported (CC BY-NC-ND3.0) Licence (http://creativecommons.org/licenses/by-nc-nd/3.0/) which permits unrestricted noncommercial use, distribution, and reproduction in any medium, provided the original work is properly cited. Please cite this article as: Gül Ş, Şahinoğlu S. Mystery of Anatomy: Robert Knox. Anatomy 2019;13(2):126-135. 